\title{
SISTEM PENDUKUNG KEPUTUSAN PENERIMAAN KARYAWAN MENGGUNAKAN METODE SIMPLE ADDITVE WEIGHTING (SAW) PADA PT. PONNY EKSPRESS SUKSESTAMA JAKARTA
}

\section{DECISION SUPPORT SYSTEM OF EMPLOYEE ACCEPTANCE BY USING THE SIMPLE ADDITIVE WEIGHTING (SAW) METHOD AT PT. PONNY EKSPRESS SUKSESTAMA JAKARTA}

\author{
Lia Mazia ${ }^{1}$, Lilyani Astri Utami ${ }^{2}$, M. Bayu Himawan ${ }^{3}$, Arum Dwi Lestari ${ }^{4}$, Mila Aprilia ${ }^{5}$ \\ Program Studi Sistem Informasi \\ STMIK Nusa Mandiri \\ Email : lia.lmz@ nusamandiri.ac.id
}

\begin{abstract}
Abstrak
Pada perusahaan yang bonafit terdapat sumber daya manusia unggul yang di kembangkan untuk mencapai keuntungan bisnis. Untuk mendapatkan sumber daya manusia yang berkualitas sesuai dengan kebutuhan perusahaan membutuhkan waktu yang tidak sebentar. Sebagai acuan dalam pengambilan keputusan pada proses seleksi calon karyawan dimulai dari penentuan kriteria yang tepat hingga pengadaan serangkaian test. Tujuan dari penelitian ini adalah membuat suatu sistem pendukung keputusan yang dapat digunakan untuk membantu proses seleksi penerimaan karyawan sesuai dengan kriteria perusahaan, sehingga proses perekrutan karyawan dapat dilakukan dengan lebih cepat dan akurat. Salah satu metode yang dapat digunakan pada sebuah pengambilan keputusan ialah metode Simple Additive Weighting (SAW). Metode SAW ini digunakan untuk menentukan nilai tertinggi dari hasil perankingan terhadap alternatif-alternatif yang ada dengan melakukan perhitungan terhadap kriteria dan bobot yang telah ditentukan. Selanjutnya penelitian ini dikembangkan menjadi sistem informasi untuk memudahkan pengguna dalam menerapkan sistem pendukung keputusan penerimaan karyawan.

Kata Kunci: Sumber Daya Manusia, Sistem Pendukung Keputusan, Simple Additive Weighting (SAW), Penerimaan Karyawan, Sistem Informasi

Abstract

There are human resources in the bonafide companies, which were developed to reach the business's profit. It also needs time to get excellent quality human resources from their needs companies. As a reference in decision-making on selecting prospective employees, there are also some tests for obtaining the proper procurement criteria. This research aims to decide on the support system, which can be used to aid the company employees' selection according to the recruitment of employees faster and more accurately. One of the methods that can be used in this decision-making is a method of Simple Additive Weighting. This SAW method is used to determine the highest value of the sequence results of several alternatives available by calculating the criteria and weights that have been selected. Next, this research was developed into information systems to facilitate users applying the support system employee admissions decisions.
\end{abstract}


Keywords: Human Resources, Decision Support Systems, Simple Additive Weighting (SAW), Employee Reception, Information Systems

\section{PENDAHULUAN}

Salah satu bagian terpenting dalam suatu perusahaan adalah Sumber Daya Manusia (SDM). Di dalam sebuah perusahaan yang bonafit terdapat sumber daya manusia unggul yang dikembangkan untuk mencapai keuntungan bisnis. Untuk mendapatkan sumber daya manusia yang berkualitas sesuai dengan kebutuhan perusahaan membutuhkan waktu yang tidak sebentar. Sebagai acuan dalam pengambilan keputusan pada proses seleksi calon karyawan mulai dari penentuan kriteria yang tepat hingga pengadaan serangkaian test.

Proses penerimaan calon karyawan pada PT. Ponny Ekspress Suksestama Jakarta sejauh ini dilakukan dengan beberapa tahapan mulai dari review data diri pelamar, wawancara hingga rangkaian test yang harus dilakukan. Akan tetapi dalam prosesnya pada beberapa kasus tidak mempertimbangkan beberapa dari kriteria yang dibutuhkan oleh perusahaan, sehingga memungkinkan adanya ketidakseimbangan dalam melakukan penilaian kualitas calon karyawan.

Dalam mendukung proses penerimaan karyawan diperlukan sebuah sistem untuk menunjang keputusan. Sistem tersebut membutuhkan metode yang digunakan untuk menentukan calon karyawan yang memenuhi kriteria perusahaan. Metode yang dapat digunakan pada sebuah pengambilan keputusan ialah Metode Simple Additive Weighting (SAW).

\section{LANDASAN TEORI}

\section{A. Rekrutmen}

Rekrutmen sebagai proses penarikan calon tenaga kerja yang dibuat oleh perusahaan agar dapat memikat pelamar dengan cara memperluas akses melalui jalur internal maupun eksternal perusahaan [1].

\section{B. Sumber Daya Manusia}

Sumber Daya Manusia (SDM) atau dalam bahasa inggris disebut dengan human resources merupakan penduduk yang bersedia, memiliki keinginan tinggi serta mampu memberikan kontribusi melalui usaha pencapaiannya terhadap suatu perusahaan [2].

\section{Sistem Penunjang Keputusan (SPK)}

Sistem Pendukung Keputusan (SPK) sebagai sistem informasi berbasis komputer yang didalamnya memiliki tiga komponen yang saling berhubungan yaitu sistem bahasa, sistem pengetahuan, serta sistem pemrosesan masalah. Masingmasing dari komponen tersebut saling berinteraksi yang diperlukan untuk mendukung pengambilan sebuah keputusan [3].

\section{Simple Additive Weighting (SAW)}

Metode Simple Additive Weighting (SAW) atau yang disebut sebagai metode pembobotan sederhana adalah sebuah metode untuk menyelesaian permasalahan dalam sebuah sistem pendukung keputusan yang dilakukan dengan cara mencari skala prioritas pada setiap alternatif di semua atribut [4].

\section{1) Langkah-langkah penyelesaian dengan menggunakan metode Simple Additive Weighting (SAW)}

Berikut merupakan langkah penyelesaian menggunakan metode Simple Additive Weighting (SAW) [5]:

a. Menentukan alternatif atau bisa ditulis dengan Ai. 
b. Menentukan kriteria atau $\mathrm{Cj}$ untuk dijadikan sebagai acuan dalam pengambilan sebuah keputusan.

c. Memberikan nilai rating kecocokan dari setiap alternatif pada setiap kriteria.

d. Menentukan bobot preferensi atau tingkat kepentingan (W) pada setiap kriteria. $\mathrm{W}=[\mathrm{W} 1, \mathrm{~W} 2, \mathrm{~W} 3, \ldots, \mathrm{WJ}]$

e. Membuat tabel rating kecocokan dari setiap alternatif pada setiap kriteria. Membuat matrik keputusan (X) yang dibentuk dari tabel rating kecocokan dari setiap alternatif pada setiap kriteria. Nilai X setiap alternatif (Ai) pada setiap kriteria $(\mathrm{Cj})$ yang sudah ditentukan, dimana, $i=1,2, \ldots m$ dan $\mathrm{j}=1,2, \ldots \mathrm{n}$.

$x=\left[\begin{array}{ccc}x_{11} & x_{12} \cdots & x_{1 j} \\ \cdot & & \cdot \\ \cdot & & \cdot \\ \cdot & & \cdot \\ x_{i 1} & x_{i 2} \cdots & x_{1 j}\end{array}\right]$

g. Melakukan normalisasi matrik keputusan dengan cara menghitung nilai rating kinerja ternomalisasi (rij) dari alternatif Ai pada kriteria $\mathrm{Cj}$.

$r i j=\left(\frac{x_{i j}}{\operatorname{Max}_{x_{i j}}}\right)$ Jika $\mathrm{j}$ adalah kriteria

keuntungan (benefit)

$r i j=\left(\frac{\operatorname{Min}_{x_{i j}}}{x_{i j}}\right)$ Jika $\mathrm{j}$ adalah kriteria

biaya (cost)

Dimana:

Ri $\mathrm{j}=$ nilai rating kinerja ternormalisasi

$\mathrm{Xi}=$ nilai atribut yang dimiliki setiap kriteria Max

$\mathrm{xij}=$ nilai terbesar dari setiap kriteria $\mathrm{i}$ Min

$\mathrm{xij}=$ nilai terkecil dari setiap kriteria $\mathrm{i}$

Benefit $=$ jika nilai terbesar adalah terbaik

Cost $=$ jika nilai terkecil adalah terbaik

h. Hasil dari nilai rating kinerja ternomalisasi (rij) akan membentuk matrik ternormalisasi $(\mathrm{R})$

$$
R=\left[\begin{array}{ccc}
r_{11} & r_{12} \cdots & r_{1 j} \\
\cdot & & \cdot \\
\cdot & & \cdot \\
\cdot & & \cdot \\
r_{i 1} & r_{i 2} \cdots & r_{1 j}
\end{array}\right]
$$

i. Perangkingan untuk setiap alternatif (Vi) diperoleh dari penjumlahan terhadap perkalian elemen baris matrik ternormalisasi (R) dengan bobot preferensi (W) yang bersesuaian eleman kolom matrik.

$$
\mathrm{vi}=\sum_{j=1}^{n} w_{j} r_{i j}
$$

Dimana:

$\mathrm{Vi}=$ rangking untuk setiap alternatif

$\mathrm{Wj}=$ bobot dari setiap kriteria

Rij = rating kinerja ternormalisasi Nilai

Vi yang lebih besar mengindikasikan bahwa alternatif Ai lebih terpilih.

Pada seleksi penerimaan karyawan terdapat 11 kriteria yang akan digunakan yaitu Kriteria C1 sampai C11.

Tabel 1. Kriteria Penelitian

\begin{tabular}{|c|l|}
\hline Kode & \multicolumn{1}{|c|}{ Kriteria } \\
\hline $\mathrm{C} 1$ & Pendidikan \\
\hline $\mathrm{C} 2$ & Usia \\
\hline $\mathrm{C} 3$ & Kemampuan Komunikasi \\
\hline $\mathrm{C} 4$ & Domisili Pelamar \\
\hline $\mathrm{C} 5$ & Kepemilikan Kendaraan \\
\hline $\mathrm{C} 6$ & Pengenalan Wilayah \\
\hline $\mathrm{C} 7$ & Pengalaman Kerja \\
\hline $\mathrm{C} 8$ & Motivasi \\
\hline $\mathrm{C} 9$ & Sikap \\
\hline $\mathrm{C} 10$ & Penampilan \\
\hline $\mathrm{C} 11$ & Tanggung Jawab \\
\hline
\end{tabular}

Sumber: Peneliti, 2020

Skala rating kecocokan yang digunakan terdiri dari empat bilangan, yaitu Kurang (K), Cukup (C), Baik (B), dan Sangat Baik (SB).

Tabel 2. Skala Rating Kecocokan 


\begin{tabular}{|l|c|}
\hline \multicolumn{1}{|c|}{ Keterangan } & Nilai Bobot \\
\hline Kurang (K) & 1 \\
\hline Cukup (C) & 2 \\
\hline Baik (B) & 3 \\
\hline Sangat Baik (SB) & 4 \\
\hline
\end{tabular}

Sumber: Peneliti, 2020

Selanjutnya dari kriteria tersebut, maka dibuat satu tingkat kepentingan kriteria berdasarkan nilai bobot yang telah ditentukan ke dalam tabel.

Tabel 3. Pembobotan Kriteria

\begin{tabular}{|c|c|c|c|}
\hline Kode & Kriteria & Nilai & Bobot \\
\hline \multirow{4}{*}{$\mathrm{Cl}$} & \multirow{4}{*}{$\begin{array}{c}\text { Pendiditan } \\
\text { (Benefit) }\end{array}$} & $\leq \mathrm{SMP}(\mathrm{K})$ & 1 \\
\hline & & SMLA (C) & 2 \\
\hline & & Diploma 3 (B) & 3 \\
\hline & & $\geq$ Sarjana (SB) & 4 \\
\hline \multirow{2}{*}{$\mathrm{C} 2_{2}$} & \multirow{2}{*}{$\begin{array}{c}\text { Usia } \\
\text { (Cost) }\end{array}$} & $\leq 30 \mathrm{Thn}(\mathrm{C})$ & 1 \\
\hline & & $\geq 30 \operatorname{Tm}(\mathrm{K})$ & 2 \\
\hline \multirow{4}{*}{$\mathrm{C}_{3}$} & \multirow{4}{*}{$\begin{array}{c}\text { Kemampuan Komurikasi } \\
\text { (Benefit) }\end{array}$} & Reaktif - Kurang Sistem atis (K) & 1 \\
\hline & & Proaktif - Kurang Sistematis (C) & 2 \\
\hline & & Reaktif - Sistematis (B) & 3 \\
\hline & & Proaktif - Sistem atis (SB) & 4 \\
\hline \multirow{3}{*}{$\mathrm{C4}$} & \multirow{3}{*}{$\begin{array}{c}\text { Domisili Pelamar } \\
\text { (Cost) }\end{array}$} & Sesuai Area (B) & $\overline{1}$ \\
\hline & & $\pm 10 \mathrm{Km}$ Dari Area (C) & 2 \\
\hline & & $\geq 10 \mathrm{Km}$ Dari Area $(\mathrm{K})$ & 3 \\
\hline \multirow{4}{*}{ C5 } & \multirow{4}{*}{$\begin{array}{c}\text { Kepeniliken Kenderaan } \\
\text { (Benefit) }\end{array}$} & Sewa $(\mathrm{K})$ & 1 \\
\hline & & Kelvarga (C) & 2 \\
\hline & & Orang Tua (B) & 3 \\
\hline & & Milik Sendiri (SB) & 4 \\
\hline \multirow{3}{*}{ C6 } & \multirow{3}{*}{$\begin{array}{c}\text { Pengena lan Wilayah } \\
\text { (Benefit) }\end{array}$} & $\leq 60 \%(\mathrm{~K})$ & 1 \\
\hline & & $60-80 \%$ (C) & 2 \\
\hline & & $80-100 \%(B)$ & 3 \\
\hline \multirow{4}{*}{$C 7$} & \multirow{4}{*}{$\begin{array}{c}\text { Pengalaman Kerja } \\
\text { (Benefit) }\end{array}$} & $O(\mathrm{~K})$ & 1 \\
\hline & & $\leq 1 \operatorname{thn}(C)$ & 2 \\
\hline & & $2-3 \operatorname{tnn}(B)$ & 3 \\
\hline & & $\geq 3 \operatorname{thn}(\mathrm{SB})$ & 4 \\
\hline \multirow{4}{*}{$\mathrm{C} 8$} & \multirow{4}{*}{$\begin{array}{l}\text { Motivasi } \\
\text { (Benefit) }\end{array}$} & Kurang (K) & 1 \\
\hline & & Cukup (C) & 2 \\
\hline & & Baìk (B) & 3 \\
\hline & & Sangat $\mathrm{Baik}(\mathrm{SB})$ & 4 \\
\hline \multirow{4}{*}{$\mathrm{Cg}$} & \multirow{4}{*}{$\begin{array}{c}\text { Sikap } \\
\text { (Benefit) }\end{array}$} & Kurang $(\mathrm{K})$ & $\overline{1}$ \\
\hline & & Culsup (C) & 2 \\
\hline & & Baik (B) & 3 \\
\hline & & Sangat Baik (SB) & 4 \\
\hline \multirow{4}{*}{$\mathrm{C} 10$} & \multirow{4}{*}{$\begin{array}{l}\text { Peram pilan } \\
\text { (Benefit) }\end{array}$} & Kurang (K) & 1 \\
\hline & & Cukup (C) & 2 \\
\hline & & Baik (B) & 3 \\
\hline & & Sangat $\mathrm{Baìk}(\mathrm{SB})$ & 4 \\
\hline \multirow{4}{*}{$\mathrm{Cll}$} & \multirow{4}{*}{$\begin{array}{c}\text { Tanggeng J awab } \\
\text { (Benefit) }\end{array}$} & Kurang $(\mathrm{K})$ & 1 \\
\hline & & Cukup (C) & 2 \\
\hline & & Baik (B) & 3 \\
\hline & & Sangat Baik (SB) & 4 \\
\hline
\end{tabular}

Sumber: Peneliti, 2020

Dari penjabaran kriteria diatas maka diberikan nilai bobot (W) berdasarkan tingkat kepentingan masing-masing kriteria.

Tabel 4. Nilai Bobot Preferensi

\begin{tabular}{|l|c|c|c|}
\hline \multicolumn{1}{|c|}{ Kriteria } & Kode & Keterangan & Nilai Bobot \\
\hline Pendidikan & C1 & Sangat penting & 4 \\
\hline Usia & C2 & Cukup & 2 \\
\hline Kemampuan Komunikasi & C3 & Sangat penting & 4 \\
\hline Domisili Pelamar & C4 & Penting & 3 \\
\hline Kepemilikan Kendaraan & C5 & Penting & 3 \\
\hline Pengenalan Wilayah & C6 & Penting & 3 \\
\hline Pengalaman Keja & C7 & Penting & 3 \\
\hline Motivasi & C8 & Penting & 3 \\
\hline Sikap & C9 & Penting & 3 \\
\hline Penampilan & C10 & Penting & 3 \\
\hline Tanggung Jawab & C11 & Sangat penting & 4 \\
\hline
\end{tabular}

Sumber: Peneliti, 2020

\section{METODE PENELITIAN}

Metode yang digunakan dalam penelitian ini adalah metode penelitian deskriptif kuantitatif merupakan langkahlangkah sistematis yang menggunakan tahapan penelitian dengan pendekatan kuantitatif untuk mendapatkan solusi atas suatu permasalahan sehingga didapatkan sebuah informasi lebih jelas dan luas [6].

Penelitian ini melibatkan pengumpulan data, melakukan perhitungan terhadap data yang ada serta menarik hasil kesimpulan. Sedangkan penghitungan dilakukan dengan menggunakan salah satu model yang ada pada sistem pendukung keputusan yaitu metode Simple Additive Weighting (SAW).

\section{HASIL DAN PEMBAHASAN}

Adapun langkah-langkah untuk menyelesaikan masalah dengan menggunakan metode Simple Additive Weighting (SAW) sebagai berikut :

\section{A. Menentukan kriteria atau $\mathbf{C j}$}

Tabel 5. Data Calon Karyawan 


\begin{tabular}{|c|l|c|c|c|c|c|c|c|c|c|c|c|c|}
\hline \multirow{2}{*}{ N0 } & \multirow{2}{*}{ Nama Pelamar } & \multicolumn{9}{|c|}{ Ket } \\
\cline { 2 - 8 } & Cl & C2 & C3 & C4 & C5 & C6 & C7 & C8 & C9 & C10 & Cll & \\
\hline 1 & Fajar Suryohadi & C & K & K & K & K & K & K & K & K & C & K & Ditolak \\
\hline 2 & Yopi Ahmad & K & K & K & K & C & K & K & K & K & C & K & Ditolak \\
\hline 3 & M Mukhlis & C & K & K & K & K & K & K & K & K & C & K & Ditolak \\
\hline 4 & Irfan Maulana & K & K & C & K & K & K & K & K & K & C & K & Ditolak \\
\hline 5 & Rizal Pribadi & C & K & B & K & B & K & B & B & B & B & B & Diterima \\
\hline 6 & M Kumiawan & C & K & C & K & B & K & B & B & B & C & C & Diterima \\
\hline 7 & M Darwis & B & C & B & C & SB & C & K & B & B & C & B & Diterima \\
\hline 8 & Achmad Subhan & B & K & C & K & B & K & B & B & C & C & B & Diterima \\
\hline 9 & Andi Jaka & C & C & C & C & B & K & B & B & B & B & B & Diterima \\
\hline 10 & Samhudi & C & K & B & C & B & K & C & B & B & C & B & Diterima \\
\hline
\end{tabular}

Sumber : Peneliti, 2020

Keterangan :
$\mathrm{SB}=$ Sangat Baik
$\mathrm{B}=$ Baik
$\mathrm{C}=$ Cukup
$\mathrm{K}=$ Kurang

B. Dari tabel rating kecocokan dari setiap alternatif pada setiap kriteria tersebut dibuat sebuah matrik keputusan (X).

Tabel 6. Rating Kecocokan Alternatif

Per Kriteria

\begin{tabular}{|c|c|c|c|c|c|c|c|c|c|c|c|c|}
\hline \multirow{2}{*}{ No } & \multirow{2}{*}{ Alternatif } & \multicolumn{10}{|c|}{ Nilai kriteria } \\
\cline { 2 - 13 } & & C1 & C2 & C3 & C4 & C5 & C6 & C7 & C8 & C9 & C10 & C11 \\
\hline 1 & A1 & 2 & 2 & 1 & 3 & 1 & 1 & 1 & 1 & 1 & 2 & 1 \\
\hline 2 & A2 & 1 & 2 & 1 & 3 & 2 & 1 & 1 & 1 & 1 & 2 & 1 \\
\hline 3 & A3 & 2 & 2 & 1 & 3 & 1 & 1 & 1 & 1 & 1 & 2 & 1 \\
\hline 4 & A4 & 1 & 2 & 2 & 3 & 1 & 1 & 1 & 1 & 1 & 2 & 1 \\
\hline 5 & A5 & 2 & 2 & 3 & 3 & 3 & 1 & 3 & 3 & 3 & 3 & 3 \\
\hline 6 & A6 & 2 & 2 & 2 & 3 & 3 & 1 & 3 & 3 & 3 & 2 & 2 \\
\hline 7 & A7 & 3 & 1 & 3 & 2 & 4 & 2 & 1 & 3 & 3 & 2 & 3 \\
\hline 8 & A8 & 3 & 2 & 2 & 3 & 3 & 1 & 3 & 3 & 2 & 2 & 3 \\
\hline 9 & A9 & 2 & 1 & 2 & 2 & 3 & 1 & 3 & 3 & 3 & 3 & 3 \\
\hline 10 & A10 & 2 & 2 & 3 & 2 & 3 & 1 & 2 & 3 & 3 & 2 & 3 \\
\hline
\end{tabular}

Sumber: Peneliti, 2020

Table rating kecocokan di atas kemudian diubah menjadi sebuah matriks keputusan $\mathrm{X}$ seperti yang ditampilkan berikut ini:

$$
X=\left\{\begin{array}{lllllllllll}
2 & 2 & 1 & 3 & 1 & 1 & 1 & 1 & 1 & 2 & 1 \\
1 & 2 & 1 & 3 & 2 & 1 & 1 & 1 & 1 & 2 & 1 \\
2 & 2 & 1 & 3 & 1 & 1 & 1 & 1 & 1 & 2 & 1 \\
1 & 2 & 2 & 3 & 1 & 1 & 1 & 1 & 1 & 2 & 1 \\
2 & 2 & 3 & 3 & 3 & 1 & 3 & 3 & 3 & 3 & 3 \\
2 & 2 & 2 & 3 & 3 & 1 & 3 & 3 & 3 & 2 & 2 \\
3 & 1 & 3 & 2 & 4 & 2 & 1 & 3 & 3 & 2 & 3 \\
3 & 2 & 2 & 3 & 3 & 1 & 3 & 3 & 2 & 2 & 3 \\
2 & 1 & 2 & 2 & 3 & 1 & 3 & 3 & 3 & 3 & 3 \\
2 & 2 & 3 & 2 & 3 & 1 & 2 & 3 & 3 & 2 & 3
\end{array}\right\}
$$

\section{Melakukan Normalisasi Matriks} Keputusan

Tabel 7. Atribut Kriteria Cost dan Benefit

\begin{tabular}{|c|l|l|}
\hline Kode & \multicolumn{1}{|c|}{ Kriteria } & \multicolumn{1}{c|}{ CostBenefit } \\
\hline C1 & Pendidikan & Benefit \\
\hline C2 & Usia & Cost \\
\hline C3 & Kemampuan Komunikasi & Benefit \\
\hline C4 & Domisili Pelamar & Cost \\
\hline C5 & Kepemilikan Kendaraan & Benefit \\
\hline C6 & Pengenalan Wilayah & Benefit \\
\hline C7 & Pengalaman Kerja & Benefit \\
\hline C8 & Motivasi & Benefit \\
\hline C9 & Sikap & Benefit \\
\hline C10 & Penampilan & Benefit \\
\hline C11 & Tanggung Jawab & Benefit \\
\hline
\end{tabular}

Sumber: Peneliti, 2020

1) Kriteria pendidikan masuk ke dalam atribut benefit.

$$
\begin{aligned}
& R 11=\frac{2}{\operatorname{Max}(2121223322)}=\frac{2}{3}=0,67 \\
& R 21=\frac{1}{\operatorname{Max}(2121223322)}=\frac{1}{3}=0,33 \\
& R 31=\frac{2}{\operatorname{Max}(2121223322)}=\frac{2}{3}=0,67 \\
& R 41=\frac{1}{\operatorname{Max}(2121223322)}=\frac{1}{3}=0,33 \\
& R 51=\frac{2}{\operatorname{Max}(2121223322)}=\frac{2}{3}=0,67 \\
& R 61=\frac{2}{\operatorname{Max}(2121223322)}=\frac{2}{3}=0,67 \\
& R 71=\frac{3}{\operatorname{Max}(2121223322)}=\frac{3}{3}=1 \\
& R 81=\frac{3}{\operatorname{Max}(2121223322)}=\frac{3}{3}=1 \\
& R 91=\frac{2}{\operatorname{Max}(2121223322)}=\frac{2}{3}=0,67 \\
& R 101=\frac{2}{\operatorname{Max}(2121223322)}=\frac{2}{3}=0,67
\end{aligned}
$$


2) Kriteria usia masuk ke dalam atribut cost.

$$
\begin{aligned}
& R 12=\frac{\operatorname{Min}(2222221212)}{2}=\frac{1}{2}=0,5 \\
& R 22=\frac{\operatorname{Min}(222221212)}{2}=\frac{1}{2}=0,5 \\
& R 32=\frac{\operatorname{Min}(222221212)}{2}=\frac{1}{2}=0,5 \\
& R 42=\frac{\operatorname{Min}(222221212)}{2}=\frac{1}{2}=0,5 \\
& R 52=\frac{\operatorname{Min}(222221212)}{2}=\frac{1}{2}=0,5 \\
& R 62=\frac{\operatorname{Min}(222221212)}{2}=\frac{1}{2}=0,5 \\
& R 72=\frac{\operatorname{Min}(222221212)}{1}=\frac{1}{1}=1 \\
& R 82=\frac{\operatorname{Min}(222221212)}{2}=\frac{1}{2}=0,5 \\
& R 92=\frac{\operatorname{Min}(222221212)}{1}=\frac{1}{1}=1 \\
& R 102=\frac{\operatorname{Min}(222221212)}{2}=\frac{1}{2}=0,5
\end{aligned}
$$

3) Kriteria kemampuan komunikasi masuk ke dalam atribut benefit.

$$
\begin{aligned}
& R 13=\frac{1}{\operatorname{Max}(1112323223)}=\frac{1}{3}=0,33 \\
& R 23=\frac{1}{\operatorname{Max}(1112323223)}=\frac{1}{3}=0,33 \\
& R 33=\frac{1}{\operatorname{Max}(1112323223)}=\frac{1}{3}=0,33 \\
& R 43=\frac{2}{\operatorname{Max}(1112323223)}=\frac{2}{3}=0,67 \\
& R 53=\frac{3}{\operatorname{Max}(1112323223)}=\frac{3}{3}=1 \\
& R 63=\frac{2}{\operatorname{Max}(1112323223)}=\frac{2}{3}=0,67 \\
& R 73=\frac{3}{\operatorname{Max}(1112323223)}=\frac{3}{3}=1 \\
& R 83=\frac{2}{\operatorname{Max}(1112323223)}=\frac{2}{3}=0,67 \\
& R 93=\frac{2}{\operatorname{Max}(1112323223)}=\frac{2}{3}=0,67 \\
& R 103=\frac{3}{\operatorname{Max}(1112323223)}=\frac{3}{3}=1
\end{aligned}
$$

4) Kriteria domisili pelamar masuk ke dalam atribut cost.

$$
\begin{aligned}
& R 14=\frac{\operatorname{Min}(3333332322)}{3}=\frac{2}{3}=0,67 \\
& R 24=\frac{\operatorname{Min}(3333332322)}{3}=\frac{2}{3}=0,67 \\
& R 34=\frac{\operatorname{Min}(3333332322)}{3}=\frac{2}{3}=0,67 \\
& R 44=\frac{\operatorname{Min}(3333332322)}{3}=\frac{2}{3}=0,67 \\
& R 54=\frac{\operatorname{Min}(3333332322)}{3}=\frac{2}{3}=0,67
\end{aligned}
$$

$$
\begin{aligned}
& R 64=\frac{\operatorname{Min}(3333332322)}{3}=\frac{2}{3}=0,67 \\
& R 74=\frac{\operatorname{Min}(3333332322)}{2}=\frac{2}{2}=1 \\
& R 84=\frac{\operatorname{Min}(3333332322)}{3}=\frac{2}{3}=0,67 \\
& R 94=\frac{\operatorname{Min}(3333332322)}{2}=\frac{2}{2}=1 \\
& R 104=\frac{M i n(3333332322)}{2}=\frac{2}{2}=1
\end{aligned}
$$

5) Kriteria Kepemilikan kendaraan masuk ke dalam atribut benefit.

$$
\begin{aligned}
& R 15=\frac{1}{\operatorname{Max}(1211334333)}=\frac{1}{4}=0,25 \\
& R 25=\frac{2}{\operatorname{Max}(1211334333)}=\frac{2}{4}=0,5 \\
& R 35=\frac{1}{\operatorname{Max}(1211334333)}=\frac{1}{4}=0,25 \\
& R 45=\frac{1}{\operatorname{Max}(1211334333)}=\frac{1}{4}=0,25 \\
& R 55=\frac{3}{\operatorname{Max}(1211334333)}=\frac{3}{4}=0,75 \\
& R 65=\frac{3}{\operatorname{Max}(1211334333)}=\frac{3}{4}=0,75 \\
& R 75=\frac{4}{\operatorname{Max}(1211334333)}=\frac{3}{4}=1 \\
& R 85=\frac{3}{\operatorname{Max}(1211334333)}=\frac{3}{4}=0,75 \\
& R 95=\frac{3}{\operatorname{Max}(1211334333)}=\frac{3}{4}=0,75 \\
& R 105=\frac{3}{\operatorname{Max}(1211334333)}=\frac{3}{4}=0,75
\end{aligned}
$$

6) Kriteria Pengenalan wilayah masuk ke dalam atribut benefit.

$$
\begin{aligned}
& R 16=\frac{1}{\operatorname{Max}(1111112111)}=\frac{1}{2}=0,5 \\
& R 26=\frac{1}{\operatorname{Max}(1111112111)}=\frac{1}{2}=0,5 \\
& R 36=\frac{1}{\operatorname{Max}(1111112111)}=\frac{1}{2}=0,5 \\
& R 46=\frac{1}{\operatorname{Max}(1111112111)}=\frac{1}{2}=0,5 \\
& R 56=\frac{1}{\operatorname{Max}(1111112111)}=\frac{1}{2}=0,5 \\
& R 66=\frac{1}{\operatorname{Max}(1111112111)}=\frac{1}{2}=0,5 \\
& R 76=\frac{2}{\operatorname{Max}(1111112111)}=\frac{2}{2}=1 \\
& R 86=\frac{1}{\operatorname{Max}(1111112111)}=\frac{1}{2}=0,5 \\
& R 96=\frac{1}{\operatorname{Max}(1111112111)}=\frac{1}{2}=0,5 \\
& R 106=\frac{1}{\operatorname{Max}(1111112111)}=\frac{1}{2}=0,5
\end{aligned}
$$


7) Kriteria pengalaman kerja masuk ke dalam atribut benefit

$R 17=\frac{1}{\operatorname{Max}(1111331332)}=\frac{1}{3}=0,33$
$R 27=\frac{1}{\operatorname{Max}(1111331332)}=\frac{1}{3}=0,33$
$R 37=\frac{1}{\operatorname{Max}(1111331332)}=\frac{1}{3}=0,33$
$R 47=\frac{1}{\operatorname{Max}(1111331332)}=\frac{1}{3}=0,33$
$R 57=\frac{3}{\operatorname{Max}(1111331332)}=\frac{3}{3}=1$
$R 67=\frac{3}{\operatorname{Max}(1111331332)}=\frac{1}{3}=1$
$R 77=\frac{1}{\operatorname{Max}(1111331332)}=\frac{1}{3}=0,33$
$R 87=\frac{3}{\operatorname{Max}(1111331332)}=\frac{3}{3}=1$
$R 97=\frac{3}{\operatorname{Max}(1111331332)}=\frac{3}{3}=1$
$R 107=\frac{2}{\operatorname{Max}(1111331332)}=\frac{2}{3}=0,67$

8) Kriteria Motivasi masuk ke dalam atribut benefit

$R 18=\frac{1}{\operatorname{Max}(1111333333)}=\frac{1}{3}=0,33$

$R 28=\frac{1}{\operatorname{Max}(1111333333)}=\frac{1}{3}=0,33$

$R 38=\frac{1}{\operatorname{Max}(1111333333)}=\frac{1}{3}=0,33$

$R 48=\frac{1}{\operatorname{Max}(1111333333)}=\frac{1}{3}=0,33$

$R 58=\frac{3}{\operatorname{Max}(1111333333)}=\frac{3}{3}=1$

$R 68=\frac{3}{\operatorname{Max}(1111333333)}=\frac{3}{3}=1$

$R 78=\frac{3}{\operatorname{Max}(111133333)}=\frac{3}{3}=1$

$R 88=\frac{3}{\operatorname{Max}(1111333333)}=\frac{3}{3}=1$

$R 98=\frac{3}{\operatorname{Max}(1111333333)}=\frac{3}{3}=1$

$R 108=\frac{3}{\operatorname{Max}(1111333333)}=\frac{3}{3}=1$

9) Kriteria Sikap masuk ke dalam atribut benefit

$R 19=\frac{1}{\operatorname{Max}(1111333233)}=\frac{1}{3}=0,33$

$R 29=\frac{1}{\operatorname{Max}(1111333233)}=\frac{1}{3}=0,33$

$R 39=\frac{1}{\operatorname{Max}(1111333233)}=\frac{1}{3}=0,33$

$R 49=\frac{1}{\operatorname{Max}(1111333233)}=\frac{1}{3}=0,33$

$$
\begin{aligned}
& R 59=\frac{3}{\operatorname{Max}(1111333233)}=\frac{3}{3}=1 \\
& R 69=\frac{3}{\operatorname{Max}(1111333233)}=\frac{3}{3}=1 \\
& R 79=\frac{3}{\operatorname{Max}(1111333233)}=\frac{3}{3}=1 \\
& R 89=\frac{2}{\operatorname{Max}(1111333233)}=\frac{2}{3}=0,67 \\
& R 99=\frac{3}{\operatorname{Max}(1111333233)}=\frac{3}{3}=1 \\
& R 109=\frac{3}{\operatorname{Max}(1111333233)}=\frac{3}{3}=1
\end{aligned}
$$

10) Kriteria Penampilan masuk ke dalam atribut benefit

$R 110=\frac{2}{\operatorname{Max}(2222322232)}=\frac{2}{3}=0,67$

$R 210=\frac{2}{\operatorname{Max}(2222322232)}=\frac{2}{3}=0,67$

$R 310=\frac{2}{\operatorname{Max}(2222322232)}=\frac{2}{3}=0,67$

$R 410=\frac{2}{\operatorname{Max}(2222322232)}=\frac{2}{3}=0,67$

$R 510=\frac{3}{\operatorname{Max}(2222322232)}=\frac{3}{3}=1$

$R 610=\frac{2}{\operatorname{Max}(2222322232)}=\frac{2}{3}=0,67$

$R 710=\frac{2}{\operatorname{Max}(2222322232)}=\frac{2}{3}=0,67$

$R 810=\frac{2}{\operatorname{Max}(2222322232)}=\frac{2}{3}=0,67$

$R 910=\frac{3}{\operatorname{Max}(2222322232)}=\frac{3}{3}=1$

$R 1010=\frac{2}{\operatorname{Max}(2222322232)}=\frac{2}{3}=0,67$

11) Kriteria Tanggung Jawab masuk ke dalam atribut benefit

$R 111=\frac{1}{\operatorname{Max}(1111323333)}=\frac{1}{3}=0,33$

$R 211=\frac{1}{\operatorname{Max}(1111323333)}=\frac{1}{3}=0,33$

$R 311=\frac{1}{\operatorname{Max}(1111323333)}=\frac{1}{3}=0,33$

$R 411=\frac{1}{\operatorname{Max}(1111323333)}=\frac{1}{3}=0,33$

$R 511=\frac{3}{\operatorname{Max}(1111323333)}=\frac{3}{3}=1$

$R 611=\frac{2}{\operatorname{Max}(1111323333)}=\frac{2}{3}=0,67$

$R 711=\frac{3}{\operatorname{Max}(1111323333)}=\frac{3}{3}=1$

$R 811=\frac{3}{\operatorname{Max}(1111323333)}=\frac{3}{3}=1$

$R 911=\frac{3}{\operatorname{Max}(1111323333)}=\frac{3}{3}=1$

$R 1011=\frac{3}{\operatorname{Max}(1111323333)}=\frac{3}{3}=1$ 
D. Hasil matrik ternormalisasi $(\mathbf{R})$

$R=\left\{\begin{array}{ccccccccccc}0,67 & 0,5 & 0,33 & 0,67 & 0,25 & 0,5 & 0,33 & 0,33 & 0,33 & 0,67 & 0,33 \\ 0,33 & 0,5 & 0,33 & 0,67 & 0,5 & 0,5 & 0,33 & 0,33 & 0,33 & 0,67 & 0,33 \\ 0,67 & 0,5 & 0,33 & 0,67 & 0,25 & 0,5 & 0,33 & 0,33 & 0,33 & 0,67 & 0,33 \\ 0,33 & 0,5 & 0,67 & 0,67 & 0,25 & 0,5 & 0,33 & 0,33 & 0,33 & 0,67 & 0,33 \\ 0,67 & 0,5 & 1 & 0,67 & 0,75 & 0,5 & 1 & 1 & 1 & 1 & 1 \\ 0,67 & 0,5 & 0,67 & 0,67 & 0,75 & 0,5 & 1 & 1 & 1 & 0,67 & 0,67 \\ 1 & 1 & 1 & 1 & 1 & 1 & 0,33 & 1 & 1 & 0,67 & 1 \\ 1 & 0,5 & 0,67 & 0,67 & 0,75 & 0,5 & 1 & 1 & 0,67 & 0,67 & 1 \\ 0,67 & 1 & 0,67 & 1 & 0,75 & 0,5 & 1 & 1 & 1 & 1 & 1 \\ 0,67 & 0,5 & 1 & 1 & 0,75 & 0,5 & 0,67 & 1 & 1 & 0,67 & 1\end{array}\right\}$

\section{E. Melakukan proses perangkingan}

Nilai bobot W yaitu:

$[4,2,4,3,3,3,3,3,3,3,4]$

$$
\begin{aligned}
& \mathrm{V} 1=(0,67 \times 4)+(0,5 \times 2)+(0,33 \times 4)+ \\
&(0,67 \times 3)+(0,25 \times 3)+(0,5 \times 3)+ \\
&(0,33 \times 3)+(0,33 \times 3)+(0,33 \times 3)+ \\
&(0,67 \times 3)+(0,33 \times 4) \\
&= 2,68+1+1,32+2,01+0,75+1,5+ \\
& 0,99+0,99+0,99+2,01+1,32 \\
&= \mathbf{1 5 , 5 6} \\
& \mathrm{V} 2=(0,33 \times 4)+(0,5 \times 2)+(0,33 \times 4)+ \\
&(0,67 \times 3)+(0,5 \times 3)+(0,5 \times 3)+ \\
&(0,33 \times 3)+(0,33 \times 3)+(0,33 \times 3)+ \\
&(0,67 \times 3)+(0,33 \times 4) \\
&= 1,32+1+1,32+2,01+1,5+1,5+ \\
& 0,99+0,99+0,99+2.01+1,32
\end{aligned}
$$$$
=15
$$$$
\mathrm{V} 3=(0,67 \times 4)+(0,5 \times 2)+(0,33 \times 4)+
$$$$
(0,67 \times 3)+(0,25 \times 3)+(0,5 \times 3)+
$$$$
(0,33 \times 3)+(0,33 \times 3)+(0,33 \times 3)+
$$$$
(0,67 \times 3)+(0,33 \times 4)
$$$$
=2,68+1+1,32+2,01+0,75+1,5
$$$$
+0,99+0,99+0,99+2,01+1,32
$$$$
=\mathbf{1 5 , 5 6}
$$

$$
\mathrm{V} 4=(0,33 \times 4)+(0,5 \times 2)+(0,67 \times 4)+
$$$$
(0,67 \times 3)+(0,25 \times 3)+(0,5 \times 3)+
$$$$
(0,33 \times 3)+(0,33 \times 3)+(0,33 \times 3)
$$$$
+(0,67 \times 3)+(0,33 \times 4)
$$$$
=1,32+1+2,68+2,01+0,75+1,5
$$$$
+0,99+0,99+0,99+2,01+1,32
$$

$=\mathbf{1 5 , 5 6}$

$\mathrm{V} 5=(0,67 \times 4)+(0,5 \times 2)+(1 \times 4)+$ $(0,67 \times 3)+(0,75 \times 3)+(0,5 \times 3)+$

$$
\begin{aligned}
& (1 \times 3)+(1 \times 3)+(1 \times 3)+(1 \times 3)+ \\
& (1 \times 4) \\
= & 2,68+1+4+2,01+2,25+1,5+3 \\
& +3+3+3+4 \\
= & \mathbf{2 9}, 44 \\
\mathrm{~V} 6= & (0,67 \times 4)+(0,5 \times 2)+(0,67 \times 4)+ \\
& (0,67 \times 3)+(0,75 \times 3)+(0,5 \times 3)+ \\
& (1 \times 3)+(1 \times 3)+(1 \times 3)+(0,67 \times \\
& 3)+(0,67 \times 4) \\
= & 2,68+1+2,68+2,01+2,25+1,5 \\
& +3+3+3+2,01+2,68 \\
= & \mathbf{2 5 , 8 1} \\
\mathrm{V7}= & (1 \times 4)+(1 \times 2)+(1 \times 4)+(1 \times 3)+ \\
& (1 \times 3)+(1 \times 3)+(0,33 \times 3)+(1 \times \\
& 3)+(1 \times 3)+(0,67 \times 3)+(1 \times 4) \\
= & 4+2+4+3+3+3+0,99+3+3 \\
& +2,01+4 \\
= & \mathbf{3 2}
\end{aligned}
$$

$\mathrm{V} 8=(1 \times 4)+(0,5 \times 2)+(0,67 \times 4)+$ $(0,67 \times 3)+(0,75 \times 3)+(0,5 \times 3)+$ $(1 \times 3)+(1 \times 3)+(0,67 \times 3)+(0,67$ $\mathrm{x} 3)+(1 \times 4)$

$=4+1+2,68+2,01+2,25+1,5+3$ $+3+2,01+2,01+4$

$$
=\mathbf{2 7 , 4 6}
$$

$\mathrm{V} 9=(0,67 \times 4)+(1 \times 2)+(0,67 \times 4)+(1$ x 3$)+(0,75 \times 3)+(0,5 \times 3)+(1 \times 3)$ $+(1 \times 3)+(1 \times 3)+(1 \times 3)+(1 \times 4)$

$=2,68+2+2,68+3+2,25+1,5+3$ $+3+3+3+4$

$=30,11$

$$
\begin{aligned}
\mathrm{V} 10= & (0,67 \times 4)+(0,5 \times 2)+(1 \times 4)+(1 \\
& \times 3)+(0,75 \times 3)+(0,5 \times 3)+ \\
& (0,67 \times 3)+(1 \times 3)+(1 \times 3)+ \\
& (0,67 \times 3)+(1 \times 4) \\
= & 2,68+1+4+3+2,25+1,5+2,01 \\
& +3+3+2,01+4
\end{aligned}
$$

$$
=28,45
$$

Calon karyawan yang dinyatakan lolos atau diterima pada PT. Ponny Ekspress Suksestama Jakarta adalah alternatif yang memiliki nilai $\geq 24,58$. Dari hasil perangkingan diatas maka dapat diketahui 
alternatif yang memenuhi syarat untuk menjadi karyawan yaitu:

1. A5 (Rizal Pribadi) dengan nilai ranking 29,44

2. A6 (M Kurniawan) dengan nilai ranking 25,81

3. A7 (M Darwis) dengan nilai ranking 32

4. A8 (Achmad Subhan) dengan nilai ranking 27,46

5. A9 (Andi Jaka) dengan nilai ranking 30,11

6. A10 (Samhudi) dengan nilai ranking 28,45 .

Perolehan nilai tertinggi yaitu dimiliki oleh A7 (M Darwis) dengan nilai ranking 31,25 .

\section{ANALISIS SISTEM}

Berikut merupakan tahapan yang dilakukan dalam proses perancangan hingga pembuatan program penerimaan karyawan pada PT. Ponny Ekspress Suksestama Jakarta.

1. Rancangan Use Case Diagram

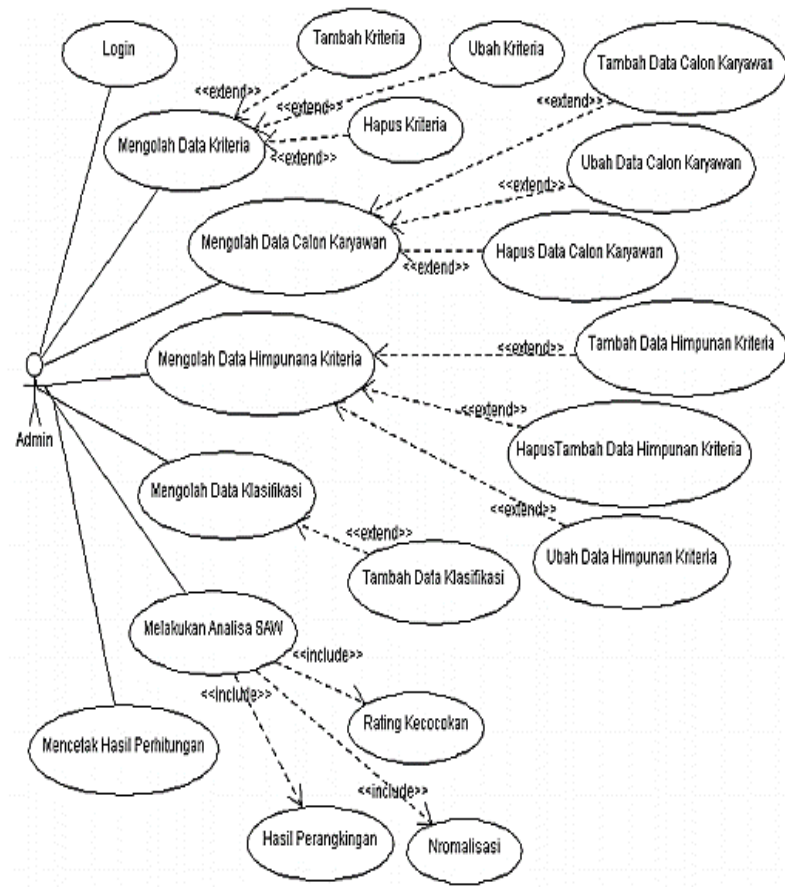

Gambar 1. Use Case Diagram

(Peneliti, 2020)

2. Rancangan Activity Diagram a. Activity Diagram Login Admin

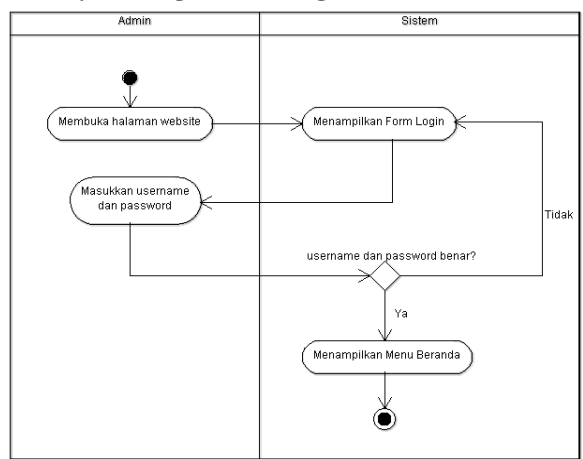

Gambar 1. Activity Diagram Login Admin

(Peneliti, 2020)

b. Activity Diagram Mengolah Data

Kriteria

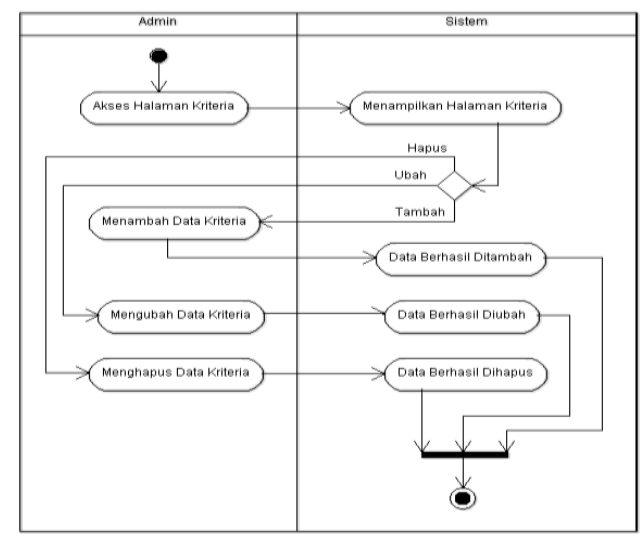

Gambar 1. Activity Diagram Mengolah Data Kriteria

(Peneliti, 2020)

c. Activity Diagram Mengolah Data Calon Karyawan

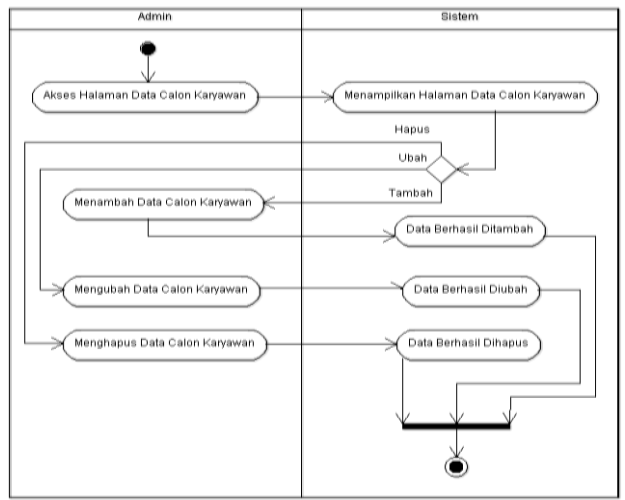

Gambar 1. Activity Diagram Mengolah Data Calon Karyawan (Peneliti, 2020) 
d. Activity Diagram Mengolah Data

Himpunan Kriteria

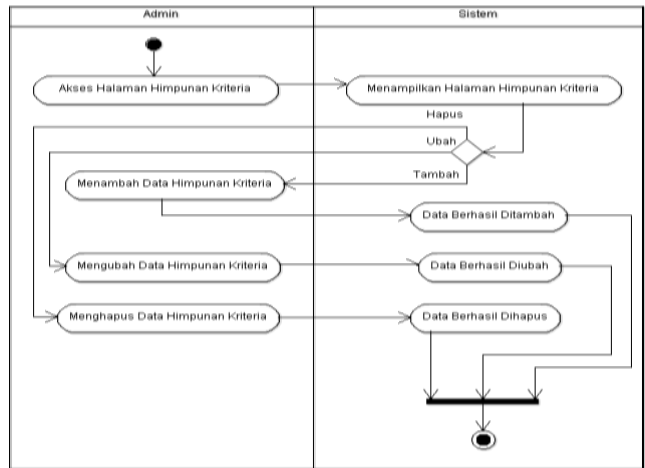

Gambar 1. Activity Diagram Mengolah Data Himpunan Kriteria

(Peneliti, 2020)

e. Activity Diagram Mengolah Data

Klasifikasi

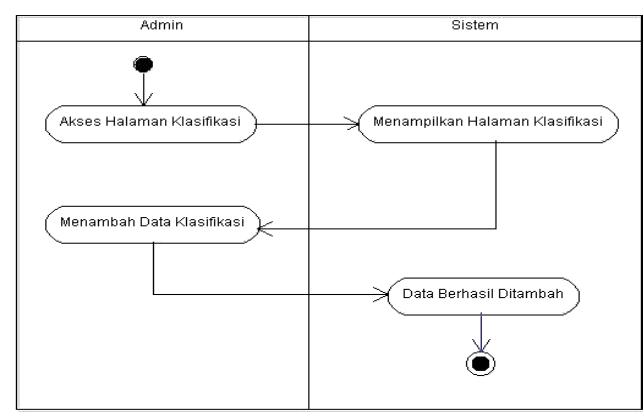

Gambar 1. Activity Diagram Mengolah Data Klasifikasi

(Peneliti, 2020)

f. Activity Diagram Melakukan Analisa SAW

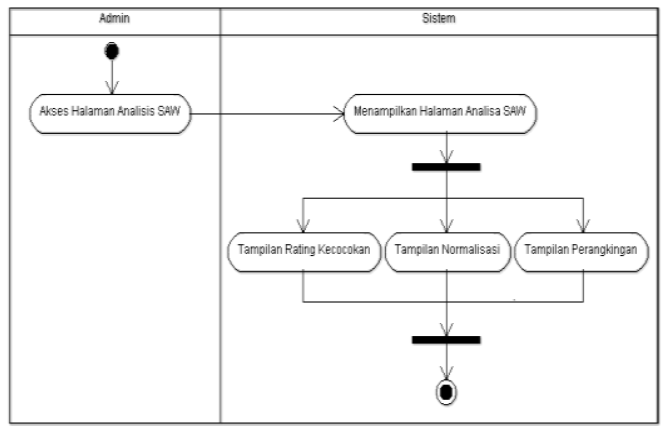

Gambar 1. Activity Diagram Melakukan Analisa SAW

(Peneliti, 2020) g. Activity Diagram Mencetak Hasil

Perhitungan

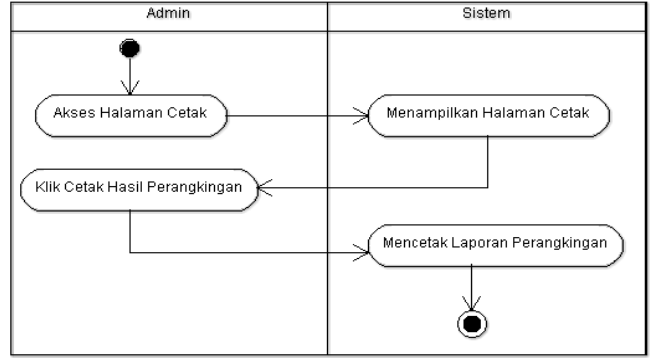

Gambar 1. Activity Diagram Mencetak Hasil Perhitungan

(Peneliti, 2020)

\section{Entity Relationship Diagram (ERD)}

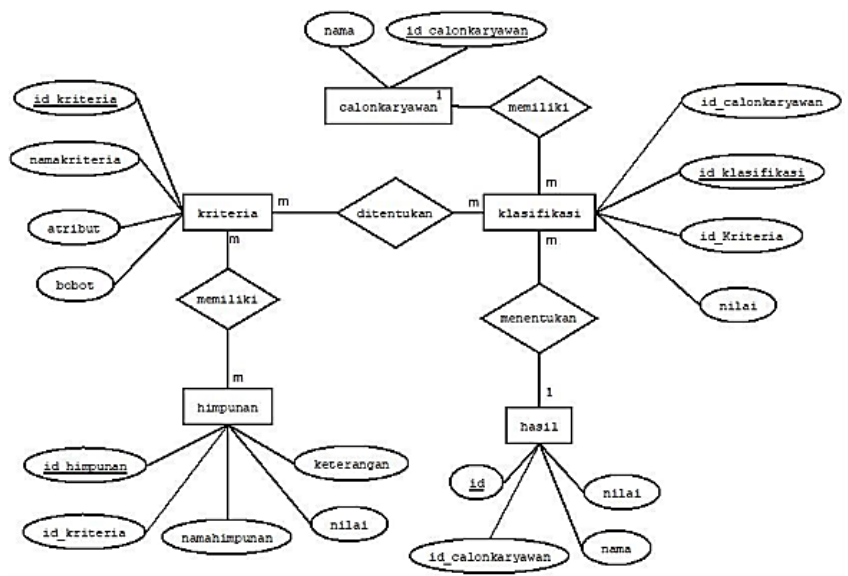

Gambar 2. Entity Relationship Diagram (ERD)

(Peneliti, 2020)

4. Logical Record Structure (LRS)

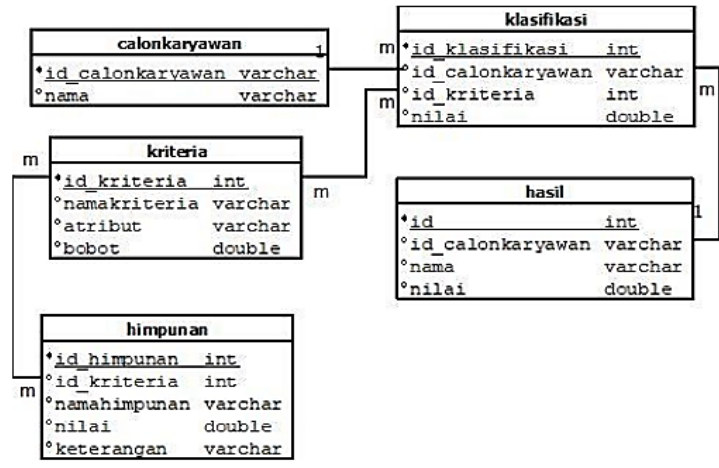

Gambar 3. Logical Record Structure (LRS)

(Peneliti, 2020)

\section{PERANCANGAN SISTEM}

Rancangan antar muka pada sistem informasi penerimaan karyawan PT. Ponny Ekspress Suksestama. 
a. Tampilan Halaman Login

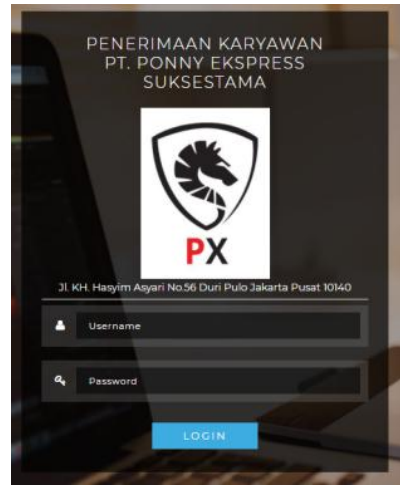

Gambar 4. Tampilan Halaman Login

(Peneliti, 2020)

b. Tampilan Halaman Beranda

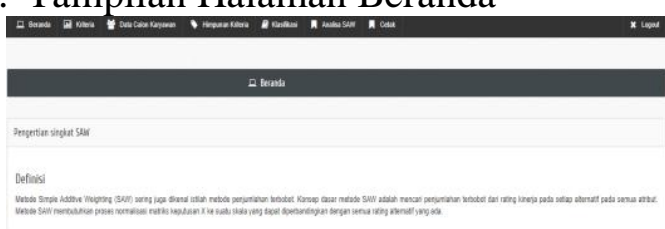

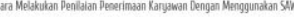

7tibmin

Gambar 5. Tampilan Halaman Beranda (Peneliti, 2020)

c. Tampilan Halaman Kriteria

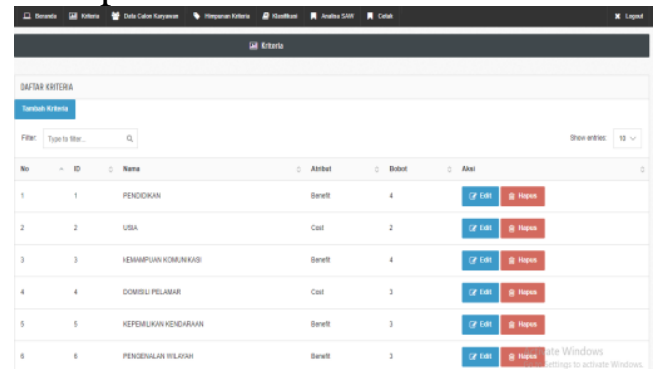

Gambar 6. Tampilan Halaman Kriteria (Peneliti, 2020)

d. Tampilan Halaman Data Calon Karyawan

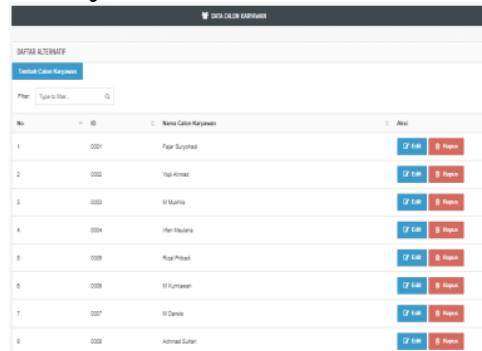

Gambar 7. Tampilan Halaman Data Calon Karyawan (Peneliti, 2020) e. Tampilan Halaman Himpunan Kriteria

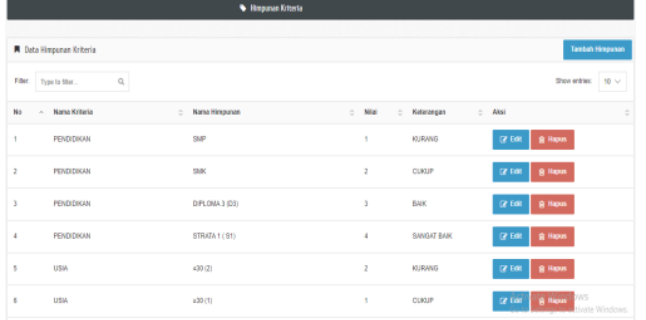

Gambar 8. Tampilan Himpunan Kriteria (Peneliti, 2020)

f. Tampilan Halaman Klasifikasi

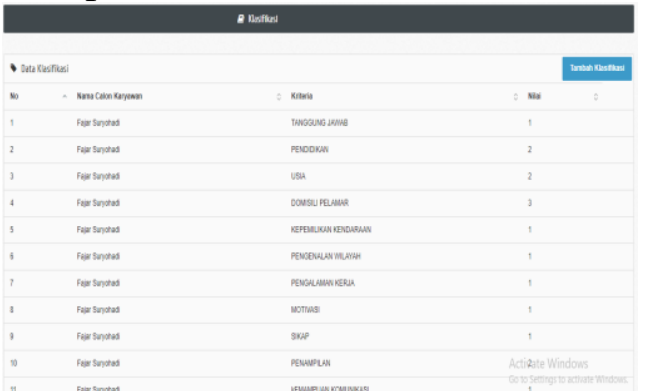

Gambar 9. Tampilan Halaman Klasifikasi (Peneliti, 2020)

\section{g. Tampilan Halaman Analisa SAW}

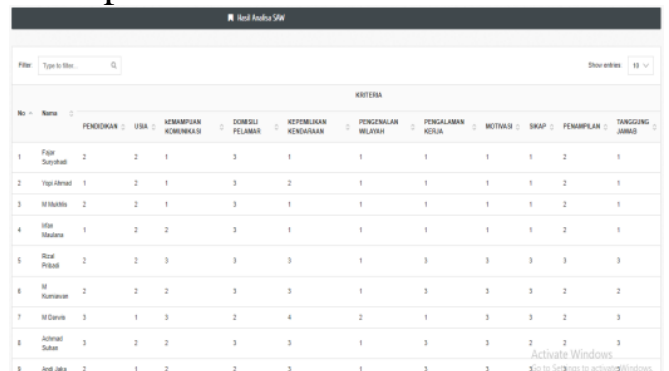

Gambar 10. Tampilan Halaman Analisa SAW

(Peneliti, 2020)

h. Tampilan Rating Kecocokan

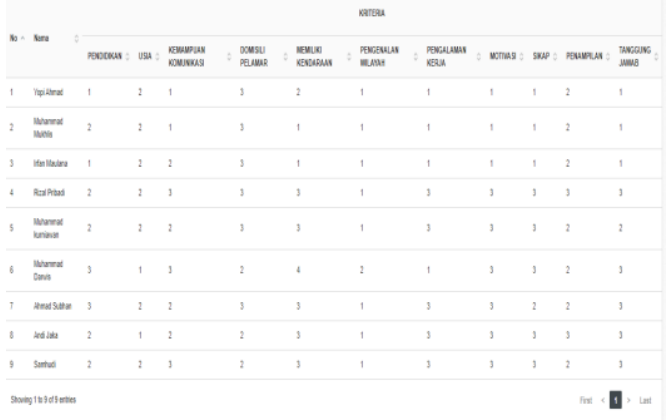

Gambar 11. Tampilan Rating Kecocokan (Peneliti, 2020) 
i. Tampilan Normalisasi

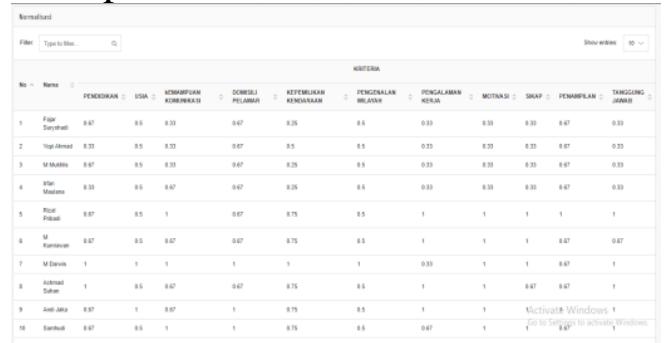

Gambar 12. Tampilan Normalisasi

(Peneliti, 2020)

\section{j. Tampilan Hasil Perangkingan}
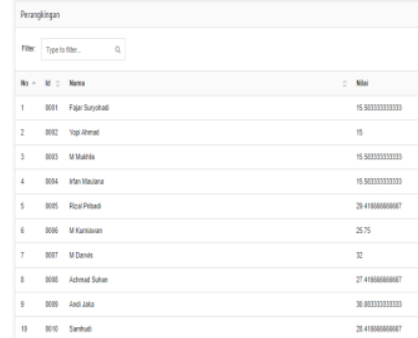

Gambar 13. Tampilan Hasil Perangkingan (Peneliti, 2020)

k. Tampilan Halaman Cetak

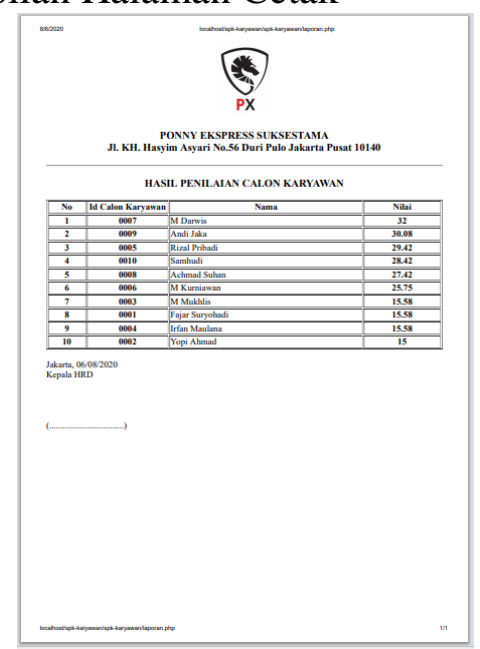

Gambar 14. Tampilan Halaman Cetak

(Peneliti, 2020)

\section{KESIMPULAN}

Berdasarkan penelitian yang telah dilakukan oleh penulis mengenai sistem pendukung keputusan penerimaan karyawan maka dapat diambil beberapa kesimpulan sebagai berikut:

1. Hasil penelitian yang telah dilakukan diimplementasikan kedalam bentuk sistem informasi penerimaan karyawan.
2. Penilaian terhadap proses penerimaan karyawan dilakukan dengan menggunakan metode Simple Additive Weighting (SAW) sehingga dapat membuat proses pengambilan keputusan menjadi lebih tepat sasaran serta mengurangi munculnya kecurangan yang disebabkan oleh penilaian secara subjektif.

3. Penilaian pada penerimaan karyawan menggunakan kriteria yang sesuai dengan apa yang dibutuhkan oleh perusahaan.

\section{DAFTAR PUSTAKA}

[1] M. Hariwijaya, Proses Rekrutmen \& Seleksi Karyawan. Yogyakarta: Elmatera, 2017.

[2] P. D. L. P. Sinambela, Manajemen Sumber Daya Manusia. Jakarta: Bumi Aksara, 2016.

[3] M. K. Dicky Nofriansyah, S.Kom., Konsep Data Mining vs Sistem Pendukung Keputusan. Yogyakarta: Deepublish, 2014.

[4] M. K. Dicky Nofriansyah, S.Kom. and M. S. Prof. Dr. Sarjon Defit, S.Kom., Multi Criteria Decision Making (MCDM). Yogyakarta: Deepublish, 2017.

[5] M. P. Drs. Ismanto Setyabudi and D. Daryanto, Panduan Praktis Penelitian Ilmiah. Yogyakarta: Gava Media, 2015.

[6] S. Alfarisi, "Sistem Prediksi Penjualan Gamis Toko QITAZ Menggunakan Metode Single Exponential Smoothing," JABE (Journal Appl. Bus. Econ., vol. 4, no. 1, pp. 80-95, 2017. 